\title{
Chapter 15. Weed Management
}

W.M. Stall

\section{CROP GROUPS}

The Environmental Protection Agency is authorized to establish tolerances for pesticide residues in raw agricultural commodities under section 408 of the Federal Food, Drug and Cosmetic Act (FFDCA) (21 USC 34a). Crop grouping regulations currently in effect enable establishment of tolerances for a group of crops based on residue data for certain crops that are representative. In other words, establishing tolerances for three specified crops in a group could also establish tolerances for pesticide use on the remainder of the commodities of that group, which may be up to 19 separate commodities.

Commodity groups or subgroups are specified in the Federal Register. A proposed rule on the Revision of Crop Groups (40 CFR 180) is under consideration at this time. To avoid confusion on specific commodities or groups that may be listed on labels, a brief summary is provided below:

\section{Beans and Peas}

If the term bean appears on the label, the material may be applied to both Phaseolus and Vigna types of beans. The Phaseolus beans include adzuki bean, field bean, kidney bean, lima bean, moth bean, mung bean, pinto bean, rice bean, runner bean, snap bean, tepary bean, urd bean, and wax bean. The Vigna beans include southernpea, cowpea, asparagus bean, catiang, Chinese long bean, and yard long bean. If the term beans is on the label, then the material may be applied to southernpeas as well as snap beans. However, if the term green bean appears, the material may be applied to only the green color snap bean, and not the wax types. Peas do not include southernpeas but include all Pisum species including English pea, edible-pod pea, snowpea, sugar pea, dwarf pea, and Cajanus cajan, the pigeon pea.

\section{Brassica (cole) Leafy Vegetables}

The Brassica leafy vegetable group includes broccoli, Brussels sprouts, cabbage, cauliflower, Chinese broccoli, broccoli raab (rapini), Chinese cabbage (bok choy, napa), Chinese mustard cabbage (gai choy), collards, kale, kohlrabi, mustard greens, rape greens and turnip greens.

If the label states brassica leafy vegetables, as does the label for Dacthal, then it may be applied to all of the com- modities in the group. If the label states only a specific commodity, such as cabbage, then only that commodity may be treated.

Beyond that, in instances where the tolerance is on cabbage, then it also includes the tight headed Chinese cabbage. Therefore, if the label states cabbage (tight headed), it may be applied to cabbage and the napa types of Chinese cabbage. The chihili types are classified as loose headed, as is bok choy.

\section{Bulb Crops}

Bulb crops include all of the Allium species except chives. Bulb crops include onions (dry and green), leek, garlic and shallot.

\section{Cucurbit Crops}

Cucurbit crops include cucumber, squash, watermelon and muskmelon along with commodities falling under these groups. Melons is a general term which designates muskmelon, including hybrids and/or varieties of Cucumis melo, and watermelon, including hybrids and/or varieties of Citrullus spp.

The term Muskmelons includes hybrids and/or varieties of Cucumis melo (including true cantaloupes, cantaloupe, casaba, Santa Claus melon, crenshaw melon, honeydew melon, honey balls, Persian melon, golden pershaw melon, mango melon, pineapple melon, and snake melon).

Summer squash includes fruits of the gourd (Cucurbitaceae) family that are consumed when immature; $100 \%$ of the fruit are edible either cooked or raw; cannot be stored once picked; have soft rinds which are easily penetrated; and if seeds were harvested, they would not germinate. Summer squash includes Cucurbita pepo (i.e. crookneck squash, straightneck squash, scallop squash, and vegetable marrow); Lagenaria spp (i.e. spaghetti squash, hyotan, cucuzza); Luffa spp (i.e. hechima, Chinese okra); Momordica spp (i.e. bitter melon, balsam pear, balsam apple, Chinese cucumber); and other varieties and/or hybrids of these species.

\section{Lettuce}

Head lettuce only applies to crisp head varieties of lettuce. Leaf lettuce applies to all leaf lettuce types, including leaf lettuce, cos (Romaine) and the butterhead variet- 
ies. The term Lettuce includes head and leaf lettuce, i.e., all types except endive and escarole. Endive is a separate tolerance group and includes endive and/or escarole.

\section{WEED MANAGEMENT}

Weeds reduce yield and quality of vegetables through direct competition for light, moisture and nutrients as well as by interference with harvest operations.

Early season competition is most critical and a major emphasis on control should be made during this period. Common amaranth reduces yields of lettuce, watermelon and muskmelon at least $20 \%$ if allowed to compete with these crops for only the first 3 weeks of growth. Weeds can be controlled, but this requires good management practices in all phases of production. Because there are many kinds of weeds, with much variation in growth habit, they obviously cannot be managed by a single method.

The incorporation of several of the following management practices into vegetable production practices increases the effectiveness for controlling weeds.

\section{Crop Competition}

An often overlooked tool in reducing weed competition is to establish a good crop stand, in which plants emerge and rapidly shade the ground. The plant that emerges first and grows the most rapidly is the plant that will have the competitive advantage. Utilization of good production management practices such as fertility, well-adapted varieties, proper water control (irrigation and drainage), and establishment of adequate plant populations is very helpful in reducing weed competition. Everything possible should be done to insure that vegetables, not weeds, have the competitive advantage.

\section{Crop Rotation}

If the same crop is planted in the same field year after year, there usually will be some weed or weeds favored by the cultural practices and herbicides used on that crop.

By rotating to other crops, the cultural practices and herbicide program are changed. This often reduces the population of specific weeds which were tolerant in the previous cropping rotation. Care should be taken, however, in not replanting vegetables back into soil treated with a non-registered herbicide. Crop injury as well as vegetables containing illegal residues may result. Check the labels for plant back limitations before application and planting rotational crops.

\section{Mechanical Control}

Mechanical control includes field preparation by plowing or discing, cultivation, mowing, hoeing and hand pull- ing of weeds. Mechanical control practices are among the oldest of weed management techniques.

Weed control is a primary reason for preparing land for crops planted in rows. Seedbed preparation by plowing or discing exposes many weed seeds to variations in light, temperature, and moisture. For some weeds, this process breaks weed-seed dormancy, leading to early season control with herbicides or additional cultivation.

Cultivate only deep enough in the row to achieve weed control; deep cultivation may prune crop roots, bring weed seeds to the surface, and disturb the soil previously treated with a herbicide. Follow the same precautions between rows.

When weeds can be controlled without cultivation, there is no advantage to cultivating. In fact, there may be disadvantages such as drying out the soil surface, bringing weed seeds to the surface, and disturbing the root system of the crop.

\section{Mulching}

The use of polyethylene mulch increases yield and earliness of vegetables. The proper injection of fumigants under the mulch will control nematodes, soil insects, soil-borne diseases and weed seeds. Mulches act as a barrier to the growth of many weeds. Nutsedge, however, is one weed that can and will grow through the mulch.

\section{Prevention}

Preventing weeds from infesting or reinfesting a field should always be considered. Weed seed may enter a field in a number of ways. It may be distributed by wind, water, machinery, in cover crop seed and other ways. Fence rows and ditch banks are often neglected when controlling weeds in the crop. Seed produced in these areas may move into the field. Weeds in these areas can also harbor insects and diseases (especially viruses) that may move onto the crop.

It is also important to clean equipment before entering fields or when moving from a field with a high weed infestation to a relatively clean field. Nutsedge tubers especially are moved easily on discs, cultivators and other equipment.

\section{Herbicides}

Properly selected herbicides are effective tools for weed control. Herbicides may be classified several ways, depending on how they are applied and their mode of action in or on the plant. Generally, herbicides are either soil applied or foliage applied. They may be selective or non-selective, and they may be either contact or translocated through the plant. For example, paraquat is a foliage applied, contact, non-selective herbicide, while atrazine 
usually is described as a soil-applied, translocated, selective herbicide.

Foliage-applied herbicides may be applied to leaves, stems and shoots of plants. Herbicides that kill only those parts of the plants which the spray touches are contact herbicides. Those herbicides that are taken into the plant and moved throughout the plant are translocated herbicides. Paraquat is a contact herbicide while glyphosate (Roundup) or Sethoxydim (Poast) are translocated herbicides.

For foliage-applied herbicides to be effective, they must enter the plant. Good coverage is very important. Most foliage applied herbicides either require the addition of a specified surfactant or a specified formulation to be used for best control.

Soil-applied herbicides are either applied to the surface or incorporated. Surface-applied herbicides require rainfall or irrigation shortly after application for best results. Lack of moisture often results in poor weed control.

Incorporated herbicides are not dependent on rainfall or irrigation and have generally given more consistent and wider-spectrum control. They do, however, require more time and equipment for incorporation.

Herbicides which specify incorporation into the soil improve the contact of the herbicide with the weed seed and/or minimize the loss of the herbicide by volatilization or photodecomposition. Some herbicides, if not incorporated, may be lost from the soil surface.

Although most soil-applied herbicides must be moved into the soil to be effective, the depth of incorporation into the soil can be used to achieve selectivity. For example, if a crop seed is planted 2 inches deep in the soil and the herbicide is incorporated by irrigation only in the top 1 inch where most of the problem weed seeds are found, the crop roots will not come in contact with the herbicide. If too much irrigation or rain moves the herbicide down into the crop seed zone or if the herbicide is incorporated mechanically too deep, crop injury may ensue.

\section{ESTIMATED EFFECTIVENESS OF RECOMMENDED HERBICIDES ON SELECTED COMMON WEEDS IN FLORIDA VEGETABLES}

Identifying the weed problems and selecting appropriate control methods are essential steps in designing or modifying a weed control program. Knowing the weed species that infest the fields is also important in selecting the correct herbicide that is effective for specific weed problems. Generally, for preplant and preemergence applications, the weed problem must be anticipated since weeds have not emerged at the time of application. This can be done by observing the field in the previous season and recording those weeds which are present and in what areas of the field they occur. These weed maps can be very useful the next season in refreshing your memory and making decisions on which herbicides to purchase. Once weed problems have been determined, the following tables can be helpful in determining the herbicide which is most effective for control of those weeds.

Table 1 and Table 2, estimating the effectiveness of control of certain herbicides, were developed from research data, herbicide labels, and the experience of research and extension workers in Florida.

The estimated effectiveness is based on recommended rates for vegetables in Florida and application procedures as specified by the label. Herbicide effectiveness may vary due to soil type, environmental conditions (rainfall, temperatures, etc.), method and time of application, as well as size of weeds. Consult the herbicide label for specific information relating to crop use and expected response of the herbicide in specific soil types. 
Table 1. Estimated effectiveness of herbicides on selected broadleaf weeds in vegetables.

\begin{tabular}{|c|c|c|c|c|c|c|c|c|c|c|c|c|c|c|}
\hline Herbicide & 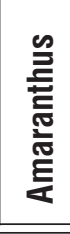 & 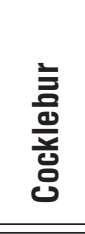 & 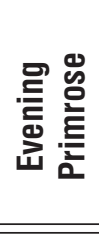 & 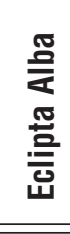 & 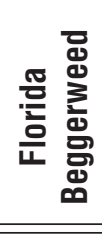 & 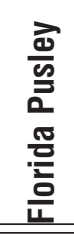 & 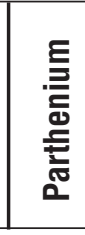 & 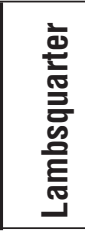 & 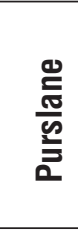 & 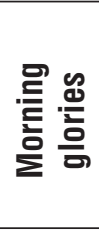 & 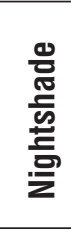 & 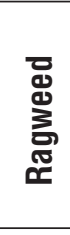 & 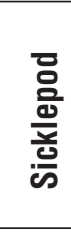 & $\begin{array}{l}\text { 응 } \\
\text { 읗 } \\
\text { 心 }\end{array}$ \\
\hline \multicolumn{15}{|c|}{ Preplant Incorporated } \\
\hline Command & $\mathrm{F}-\mathrm{G}$ & P-F & G & - & - & G & - & G-E & $\mathrm{E}$ & $P$ & - & $\mathrm{F}-\mathrm{G}$ & $P$ & - \\
\hline Dacthal & $F-G$ & $P$ & $F-G$ & - & $\mathrm{F}$ & $\mathrm{F}$ & - & G & G & $\mathrm{P}$ & $\mathrm{F}$ & - & $P$ & $\mathrm{~F}$ \\
\hline Devrinol & $F-G$ & $\mathrm{P}$ & G & $P$ & $\mathrm{P}$ & G-E & $P$ & G-E & G & $\mathrm{P}$ & $P$ & - & $\mathrm{P}$ & - \\
\hline Dual & G & $P$ & $G-E$ & G & $F-G$ & G-E & - & $F-G$ & $\mathrm{~F}$ & $P$ & $F-G$ & $\mathrm{~F}$ & $P$ & G \\
\hline Eptam & G & $\mathrm{P}$ & G & G & $\mathrm{P}$ & G-E & - & G & G & $\mathrm{F}$ & $\mathrm{P}-\mathrm{F}$ & $\mathrm{F}$ & $\mathrm{F}$ & G \\
\hline Prefar & $\mathrm{F}$ & $P$ & $\mathrm{~F}$ & $P$ & $P$ & $\mathrm{E}$ & - & $F-G$ & $\mathrm{~F}$ & $P$ & $P$ & $P$ & $P$ & $P$ \\
\hline Pursuit & G-E & - & $\mathrm{E}$ & $\mathrm{E}$ & $\mathrm{E}$ & $\mathrm{F}$ & - & $\mathrm{E}$ & $\mathrm{E}$ & G-E & G-E & G & $\mathrm{P}$ & G \\
\hline Sencor & $E$ & G & E & G & G-E & G & G & $\mathrm{E}$ & G & G-E & $P$ & G & G & G \\
\hline Treflan & $\mathrm{G}-\mathrm{E}$ & $\mathrm{P}$ & G & $\mathrm{F}-\mathrm{G}$ & $\mathrm{P}$ & $E$ & $\mathrm{P}$ & $\mathrm{G}-\mathrm{E}$ & $\mathrm{E}$ & $\mathrm{P}$ & $\mathrm{P}$ & $\mathrm{P}$ & $\mathrm{P}$ & $\mathrm{P}$ \\
\hline \multicolumn{15}{|c|}{ Preemergence } \\
\hline Alanap & G-E & $\mathrm{F}$ & G & G & $\mathrm{F}$ & G & - & $\mathrm{E}$ & G & $\mathrm{F}$ & $\mathrm{F}$ & $\mathrm{F}$ & $P$ & G \\
\hline Atrazine & E & G-E & E & G-E & G-E & $\mathrm{E}$ & $E$ & $E$ & $\mathrm{E}$ & G & G & $E$ & $F-G$ & $G-E$ \\
\hline Caparol & G-E & - & - & - & - & $F-G$ & - & $F-G$ & G-E & - & $F-G$ & $F-G$ & - & - \\
\hline Command & $F-G$ & $P$ & G & - & - & G & - & G & $E$ & $P$ & - & $\mathrm{F}$ & $P$ & - \\
\hline Curbit & G & $P$ & G & - & $P$ & $\mathrm{E}$ & $P$ & G-E & $\mathrm{E}$ & $P$ & $P$ & $P$ & $\mathrm{P}$ & $P$ \\
\hline Dacthal & $F-G$ & $\mathrm{P}$ & $F-G$ & - & $\mathrm{F}$ & $\mathrm{F}$ & - & G & $G$ & P & $\mathrm{F}$ & - & $P$ & $\mathrm{~F}$ \\
\hline Devrinol & $\mathrm{F}$ & $P$ & G & $P$ & $P$ & G & $P$ & G & G & $P$ & $P$ & - & $P$ & - \\
\hline Dual & G & $\mathrm{F}$ & G & G & $\mathrm{F}$ & G & - & $\mathrm{F}$ & P-F & $P$ & $\mathrm{~F}$ & $\mathrm{~F}$ & $P$ & G \\
\hline Goal & E & E & E & E & G & G & G & $\mathrm{E}$ & $\mathrm{E}$ & G & G & G & $\mathrm{F}$ & G \\
\hline Kerb & $F-G$ & - & G & - & - & G & - & $E$ & G-E & $F-G$ & G & - & - & - \\
\hline Lorox & G & $\mathrm{F}$ & $\mathrm{E}$ & - & G & $E$ & - & $E$ & $\mathrm{E}$ & $\mathrm{F}$ & - & G & - & $\mathrm{F}$ \\
\hline Matrix & $G-E$ & G-E & E & E & $\mathrm{E}$ & - & - & $E$ & $\mathrm{E}$ & - & $\mathrm{F}$ & G & - & - \\
\hline Prowl & G-E & $\mathrm{P}$ & G & - & $\mathrm{P}$ & G & $P$ & $E$ & G & $P$ & $P$ & $\mathrm{P}$ & $P$ & - \\
\hline Pursuit & G-E & G-E & $E$ & E & P & $\mathrm{F}$ & - & G-E & G-E & G-E & G-E & G & $P$ & G \\
\hline Sencor & G & $\mathrm{F}$ & $E$ & $F-G$ & G & G & G & $E$ & G & $\mathrm{F}$ & P-F & G & $\mathrm{G}$ & G \\
\hline \multicolumn{15}{|c|}{ Postemergence } \\
\hline Aim & $\mathrm{E}$ & - & G & G & G & G & - & $\mathrm{E}$ & G & G-E & $E$ & $\mathrm{E}$ & $E$ & $\mathrm{E}$ \\
\hline Atrazine & $G-E$ & $\mathrm{~F}$ & $E$ & G & $\mathrm{P}$ & G-E & $F-G$ & G & $F-G$ & G & $\mathrm{F}$ & $\mathrm{F}$ & $F-G$ & \\
\hline Basagran & G & G & G & G & $\mathrm{P}$ & $\mathrm{F}$ & - & - & G & $F-G$ & $F-G$ & G & $P$ & G \\
\hline Byctril & G & $E$ & $E$ & $E$ & $E$ & G-E & - & G & G-E & G & $G$ & G & - & G \\
\hline Diquat & $\mathrm{E}$ & G & $\mathrm{E}$ & $\mathrm{E}$ & G-E & G & $\mathrm{E}$ & $\mathrm{E}$ & G & $F-G$ & G & G & $\mathrm{G}$ & G \\
\hline Enquik & $E$ & G & $E$ & E & $\mathrm{E}$ & G & G & $F-G$ & G & $\mathrm{F}$ & G & G & $\mathrm{G}$ & G \\
\hline Fusilade 2000 & $\mathrm{~N}$ & $\mathrm{~N}$ & $\mathrm{~N}$ & $\mathrm{~N}$ & $\mathrm{~N}$ & $\mathrm{~N}$ & $\mathrm{~N}$ & $\mathrm{~N}$ & $\mathrm{~N}$ & $\mathrm{~N}$ & $\mathrm{~N}$ & $\mathrm{~N}$ & $\mathrm{~N}$ & $\mathrm{~N}$ \\
\hline Gramoxone/Boa & E & G & $E$ & $E$ & G-E & G & $P$ & $\mathrm{E}$ & G & $F-G$ & $\mathrm{~F}$ & G & $\mathrm{G}$ & G \\
\hline Lorox & $\mathrm{E}$ & G & - & - & G & G & - & $\mathrm{E}$ & $\mathrm{E}$ & $F-G$ & - & G & G & G \\
\hline Matrix & G & G-E & G & G & G & G & - & G-E & - & G & $\mathrm{F}$ & G & - & - \\
\hline Poast & $\mathrm{N}$ & $\mathrm{N}$ & $\mathrm{N}$ & $\mathrm{N}$ & $\mathrm{N}$ & $\mathrm{N}$ & $\mathrm{N}$ & $\mathrm{N}$ & $\mathrm{N}$ & $\mathrm{N}$ & $\mathrm{N}$ & $\mathrm{N}$ & $\mathrm{N}$ & $\mathrm{N}$ \\
\hline Pursuit & E & G & G & G & - & $\mathrm{F}$ & - & $F-G$ & P-F & G & G & G & $P$ & - \\
\hline Select & $\mathrm{N}$ & $\mathrm{N}$ & $\mathrm{N}$ & $\mathrm{N}$ & $\mathrm{N}$ & $\mathrm{N}$ & $\mathrm{N}$ & $\mathrm{N}$ & N & $\mathrm{N}$ & $\mathrm{N}$ & $\mathrm{N}$ & $\mathrm{N}$ & $\mathrm{N}$ \\
\hline Sempra/Sandea & G & G & - & - & - & $P$ & - & $P$ & $\mathrm{~F}$ & G & - & G & - & - \\
\hline Sencor & $E$ & G & G & $\mathrm{F}$ & G & G & $P$ & G & $F-G$ & $P$ & $\mathrm{P}$ & $\mathrm{F}-\mathrm{G}$ & $\mathrm{F}$ & $\mathrm{F}$ \\
\hline$E=90-100 \%$ & $\mathbf{N}=n$ & control & $\overline{G=8}$ & $-90 \%$ & $=$ - no & & $=60-\varepsilon$ & & belo & & & & & \\
\hline
\end{tabular}


Table 2. Estimated effectiveness of herbicides on selected grasses and sedges in vegetables.

\begin{tabular}{|c|c|c|c|c|c|c|c|c|c|c|}
\hline \multirow[b]{2}{*}{ Herbicide } & \multirow[b]{2}{*}{$\begin{array}{l}\text { Barnyard- } \\
\text { grass }\end{array}$} & \multirow[b]{2}{*}{$\begin{array}{c}\text { Bermuda } \\
\text {-grass }\end{array}$} & \multicolumn{2}{|c|}{ Grasses } & \multirow[b]{2}{*}{$\begin{array}{c}\text { Goose- } \\
\text { grass }\end{array}$} & \multirow[b]{2}{*}{$\begin{array}{c}\text { Panicums } \\
\text { (Fall \& Texas) }\end{array}$} & \multirow[b]{2}{*}{$\begin{array}{c}\text { Sprangle- } \\
\text { top }\end{array}$} & \multirow[b]{2}{*}{$\begin{array}{c}\text { Purple } \\
\text { Nutsedge }\end{array}$} & \multicolumn{2}{|l|}{ Sedges } \\
\hline & & & $\begin{array}{l}\text { Broadleaf } \\
\text { Signalgrass }\end{array}$ & $\begin{array}{l}\text { Crab- } \\
\text { grass }\end{array}$ & & & & & $\begin{array}{c}\text { Yellow } \\
\text { Nutsedge }\end{array}$ & $\begin{array}{l}\text { Annual } \\
\text { Sedges }\end{array}$ \\
\hline \multicolumn{11}{|c|}{ Preplant Incorporated } \\
\hline Command & E & $G-E$ & E & $\mathrm{E}$ & $E$ & G-E & - & $P$ & $P$ & $P$ \\
\hline Dacthal & G & G & $\mathrm{F}$ & G & G & $\mathrm{F}$ & - & $P$ & $P$ & $P$ \\
\hline Devrinol & $\mathrm{E}$ & E & E & $\mathrm{E}$ & $\mathrm{E}$ & G-E & - & $P$ & $\mathrm{~F}$ & $\mathrm{~F}$ \\
\hline Dual & G & G-E & $\mathrm{E}$ & $\mathrm{E}$ & $\mathrm{E}$ & G & G & P-F & G & G-E \\
\hline Eptam & $\mathrm{E}$ & $\mathrm{E}$ & G & $\mathrm{E}$ & E & $G-E$ & - & G-E & G & $\mathrm{E}$ \\
\hline Prefar & G & G & G & G & G-E & $\mathrm{F}-\mathrm{G}$ & - & $\mathrm{P}$ & $P$ & $P$ \\
\hline Pursuit & $\mathrm{F}$ & $P$ & $\mathrm{~F}$ & $\mathrm{~F}$ & $\mathrm{~F}$ & P-F & $\mathrm{P}$ & $F-G$ & G & E \\
\hline Sencor & G & $F-G$ & G & G-E & $G-E$ & $\mathrm{~F}-\mathrm{G}$ & - & $P$ & $P$ & $P$ \\
\hline Treflan & $E$ & $\mathrm{G}$ & $\mathrm{G}-\mathrm{E}$ & $\mathrm{E}$ & $\mathrm{E}$ & $\mathrm{G}$ & - & $\mathrm{P}$ & $P$ & $\mathrm{P}$ \\
\hline \multicolumn{11}{|c|}{ Preemergence } \\
\hline Alanap & $P$ & $P$ & $\mathrm{~F}$ & $\mathrm{~F}$ & $P$ & $P$ & - & $P$ & $P$ & $P$ \\
\hline Atrazine & $\mathrm{F}$ & $\mathrm{P}$ & $\mathrm{F}-\mathrm{G}$ & $\mathrm{F}$ & $\mathrm{F}$ & $P$ & $\mathrm{P}$ & $P$ & $P$ & $P$ \\
\hline Caparol & $F-G$ & $F-G$ & $F-G$ & G & $F-G$ & $\mathrm{~F}$ & - & $P$ & $P$ & $P$ \\
\hline Command & $E$ & $\mathrm{E}$ & $\mathrm{E}$ & $\mathrm{E}$ & $\mathrm{E}$ & E & - & $P$ & $P$ & $P$ \\
\hline Curbit & E & G-E & E & $E$ & E & $G-E$ & G & $P$ & $P$ & $P$ \\
\hline Dacthal & $\mathrm{F}-\mathrm{G}$ & $F-G$ & $\mathrm{~F}$ & G & G & $\mathrm{F}$ & - & $P$ & $P$ & $P$ \\
\hline Devrinol & $E$ & $E$ & E & $E$ & E & G-E & - & P-F & $\mathrm{F}$ & $F-G$ \\
\hline Dual & E & E & E & E & E & G-E & G & P-F & $F-G$ & E \\
\hline Goal & $\mathrm{F}$ & $P$ & $\mathrm{~F}$ & $\mathrm{~F}$ & $\mathrm{~F}$ & $P$ & - & $P$ & $\mathrm{~F}$ & G \\
\hline Kerb & G-E & P & G & G-E & G-E & $\mathrm{F}-\mathrm{G}$ & - & $P$ & $P$ & $P$ \\
\hline Lorox & $F-G$ & - & G & $\mathrm{G}$ & $\mathrm{G}$ & $F-G$ & - & $\mathrm{F}$ & $\mathrm{F}$ & $\mathrm{F}$ \\
\hline Prowl & $\mathrm{E}$ & $\mathrm{E}$ & $\mathrm{E}$ & $\mathrm{E}$ & $\mathrm{E}$ & $\mathrm{G}-\mathrm{E}$ & E & $P$ & $P$ & P \\
\hline Pursuit & $\mathrm{F}$ & $P$ & $\mathrm{~F}$ & $\mathrm{~F}$ & $\mathrm{~F}$ & P-F & $P$ & G & $G-E$ & E \\
\hline Sencor & $\mathrm{F}-\mathrm{G}$ & $\mathrm{F}$ & G & G & G-E & $P$ & $P$ & $\mathrm{P}$ & $\mathrm{P}$ & 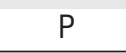 \\
\hline \multicolumn{11}{|c|}{ Postemergence } \\
\hline Aim & $\mathrm{N}$ & N & N & $\mathrm{N}$ & $\mathrm{N}$ & $\mathrm{N}$ & N & $\mathrm{N}$ & $\mathrm{N}$ & N \\
\hline Atrazine & $F-G$ & $\mathrm{~F}$ & $\mathrm{~F}$ & $\mathrm{~F}$ & $\mathrm{~F}$ & $\mathrm{~F}$ & $\mathrm{~F}$ & $P$ & $P$ & $P$ \\
\hline Basagran & $P$ & $P$ & $P$ & $P$ & $P$ & $P$ & $P$ & P-F & $F-G$ & G-E \\
\hline Buctril & $P$ & $P$ & $P$ & $P$ & $P$ & $P$ & $P$ & $P$ & $P$ & $P$ \\
\hline Diquat $^{1}$ & $E-G$ & G & E & G-E & G-E & G & G & $F-G$ & $F-G$ & G \\
\hline Enquik & P-F & P-F & P-F & P-F & P-F & P-F & - & $\mathrm{F}$ & $\mathrm{F}$ & $\mathrm{F}$ \\
\hline Fusilade & E & $\mathrm{E}$ & $E$ & $\mathrm{E}$ & $\mathrm{E}$ & $\mathrm{E}$ & E & $P$ & $P$ & $P$ \\
\hline Gramoxone/Boa ${ }^{1}$ & $\mathrm{E}$ & $\mathrm{E}$ & $\mathrm{E}$ & $\mathrm{E}$ & $\mathrm{E}$ & $\mathrm{E}$ & $\mathrm{E}$ & $F-G$ & $F-G$ & G \\
\hline Lorox & G & $F-G$ & G & G & G & G & G & $\mathrm{F}$ & $\mathrm{F}$ & $F-G$ \\
\hline Poast & $E$ & G-E & E & $E$ & $E$ & E & E & $P$ & $P$ & $P$ \\
\hline Pursuit & $\mathrm{F}$ & $P$ & P-F & P-F & $\mathrm{F}$ & P-F & $P$ & G-E & $G-E$ & G-E \\
\hline Select & E & G-E & G-E & G-E & $E$ & $E$ & E & $\mathrm{N}$ & $\mathrm{N}$ & $\mathrm{N}$ \\
\hline Sempra/Sandea & $\mathrm{N}$ & $\mathrm{N}$ & $\mathrm{N}$ & $\mathrm{N}$ & $\mathrm{N}$ & $\mathrm{N}$ & $\mathrm{N}$ & E & E & E \\
\hline Sencor & $\mathrm{F}$ & $P$ & $P$ & $\mathrm{~F}$ & $\mathrm{~F}$ & $P$ & $P$ & $P$ & $P$ & $P$ \\
\hline
\end{tabular}

